\title{
Fissicorn Tachinidæ.
}

By s. w. wiLLLIToN.

In “Entomologica Americana," iii, I 5 I, I described a peculiar genus of South American Tachinidæ with remarkably developed antennæ under the name Talarocera, in reference to the peculiar basket-shape of the organs. Figures of both male and female antennæ I give herewith. Since then two other genera of the same family with these organs abnormally developed have been described, Dichocera Williston and Diglossocera Wulp; and Brauer has recently* called attention to the fact that Walker long ago $†$ had referred two species with divided third antennal joint to a distinct genus, Schizotachina. Four of the species thus made known, Schizotachina convecta Walker, S. exul Walker, Dichocera lyrata Williston and Diglossocera bifida Wulp have the third joint somewhat similar in structure in the male. In $S$. convecta, according to the description, the joint is "divided into two parts which are equal in length, slightly curved and converge toward each other at their tips;" in S. exul, it is "divided into two parts, which are

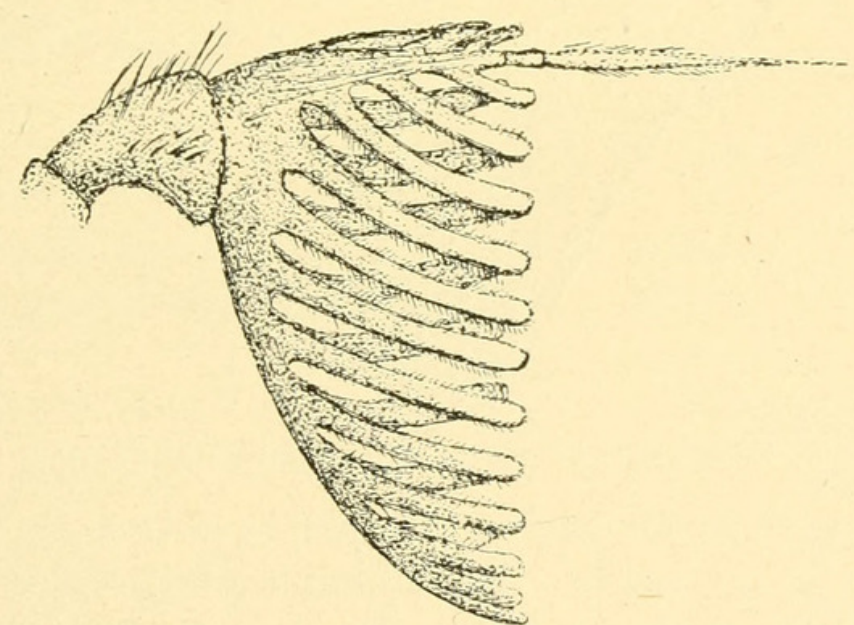

Fig. 1. Palarocera nigripennis Wied.; Antenna of male.

linear, rounded at the tips, and of equal length; upper part bent upward;" in D. lyrata, (see figure, Entom. News, Jan. I895,p. 30), the inner division has a foot-like expansion at the tip, touching the curved outer part; in $D$. bifida, the structure is similar to that in

* Sitzungsb, kaiserl. Acad. Wissensch. civ, 600.

+ Insecta Saundersia, 264.

(171) KAN. UNIV. QUAR., VOL. IV, NO. 3, JANUARY, 1896. 
S. convecta, and except that the latter is from Java and the former from the United States one might suspect that they belong to the same genus.

In Talarocera nigripennis Wied. ( T. smithin, Will.) the structure, as will be seen from the figure, is very different and exceedingly remarkable. For their description the reader is referred to the original paper. I will only add here that all the twenty-four branches are covered with microscopic hairs or pile. In front view, I have stated, the figure presented by the ends of the rods or branches is an oval one.

Professor Mik t ventures the opinion that this peculiar struc-

- ture of the male antennæ in Talarocera and Dichocera may be a monstrosity, as a somewhat similar structure has been observed by Strobl and himself in the female of Thryptocera exoleta Meigen, or at least in specimens that differ only in that character from typical forms. That Dichocera can be a monstrosity is disproved by the

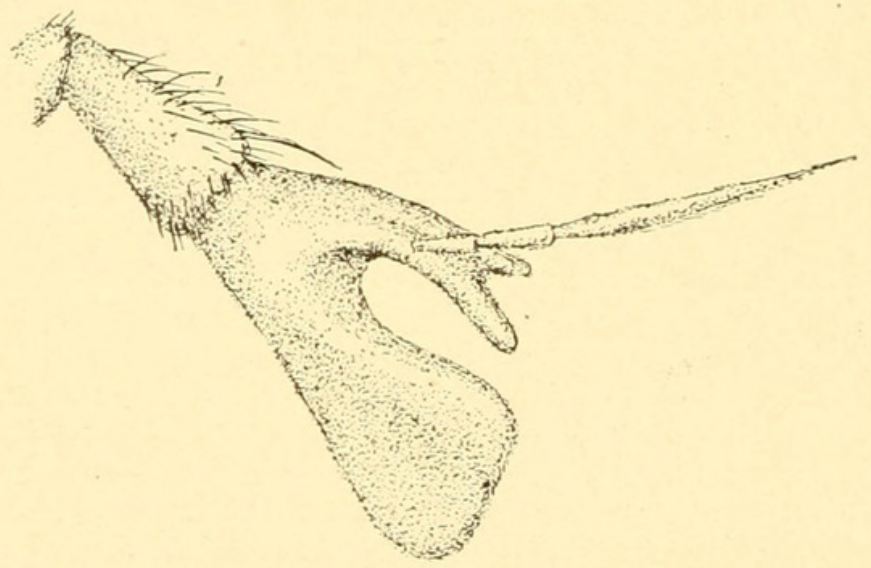

Fig. 2. Talarocera nigripennis Wied.; Antenna of female.

fact that numerous specimens of the species have since been found by Prof. Aldrich in Idaho, and others by Mr. Snow in eastern Wyoming the past summer. The distribution, it is thus seen, is wide.

Nor is it possible to consider the wonderfully elaborate structure in the male of Talarocera a monstrosity, though but a single specimen is known yet.

I may add here that Tachina insolita Walker belongs in the genus Melanophrys Will. and is possibly identical with one or the other of the described species.

\# Wiener Ent. Zeit.. May. 1895. 


\section{$2 \mathrm{BHL}$ Biodiversity Heritage Library}

Williston, Samuel W. 1896. "Fissicorn Tachinidae." The Kansas University quarterly 4, 171-172. https://doi.org/10.5962/bhl.part.7785.

View This Item Online: $\underline{\text { https://www.biodiversitylibrary.org/item/35038 }}$

DOI: https://doi.org/10.5962/bhl.part.7785

Permalink: https://www.biodiversitylibrary.org/partpdf/7785

\section{Holding Institution}

Harvard University, Museum of Comparative Zoology, Ernst Mayr Library

\section{Sponsored by}

Harvard University, Museum of Comparative Zoology, Ernst Mayr Library

\section{Copyright \& Reuse}

Copyright Status: NOT_IN_COPYRIGHT

This document was created from content at the Biodiversity Heritage Library, the world's largest open access digital library for biodiversity literature and archives. Visit BHL at https://www.biodiversitylibrary.org. 